\title{
Lernaea cyprinacea (Crustacea: Copepoda) in the Iberian Peninsula: climate implications on host-parasite interactions
}

\author{
Javier Sánchez-Hernández ${ }^{*}$ \\ Department of Zoology, Genetics and Physical Anthropology, University of Santiago de Compostela, \\ Santiago de Compostela, Spain
}

\begin{abstract}
The non-native parasitic anchor worm (Lernaea cyprinacea) may induce anaemia, malformations, reduced growth and increased susceptibility to secondary infection to its hosts. The objectives of this study were to (i) compile a list of the host species of L. cyprinacea in the Iberian Peninsula and (ii) assess if climate may impact on infestation levels of the parasite. There were two primary sources for data collection: (i) fish sampling in the Tormes Basin (Ávila, central Spain) during August 2010 and 2016 and (ii) data retrieved from publications containing relevant information about L. cyprinacea. Eleven temperature variables were obtained from Worldclim. Next, the relationship between infestation levels of the anchor worm (prevalence, intensity and abundance) and temperature was tested using mixed models. Fifteen cyprinids species among 18 species are host of L. cyprinacea in the Iberian Peninsula. Infestation levels of the anchor worm are highly connected to temperature. Finally, the possible implications of global warming for host-parasite interactions are discussed.
\end{abstract}

Keywords: alien species / ectoparasite / fish host / global warming / mixed models

Résumé - Lernaea cyprinacea (Crustacea: Copepoda) dans la péninsule ibérique : implications climatiques sur les interactions hôte-parasite. Le copépode parasite (Lernaea cyprinacea) non indigène peut induire une anémie, des malformations, une croissance réduite et une sensibilité accrue à une infection secondaire de ses hôtes. Les objectifs de cette étude étaient de (i) dresser une liste des espèces hôtes de L. cyprinacea dans la péninsule ibérique et (ii) évaluer si le climat peut avoir un impact sur les niveaux d'infestation du parasite. Il y avait deux sources principales de collecte de données: (i) l'échantillonnage des poissons dans le bassin de Tormes (Ávila, centre de l'Espagne) en août 2010 et 2016, et (ii) des données provenant de publications contenant des informations pertinentes sur L. cyprinacea. Onze variables de température ont été obtenues auprès de Worldclim. Ensuite, la relation entre les niveaux d'infestation du copépode (prévalence, intensité et abondance) et la température a été testée en utilisant des modèles mixtes. Quinze cyprinidés parmi dix-huit espèces sont hôtes de L. cyprinacea dans la péninsule ibérique. Les niveaux d'infestation de la lernée sont fortement liés à la température. Enfin, les implications possibles du réchauffement climatique pour les interactions hôte-parasite sont discutées.

Mots clés : espèces exotiques / ectoparasite / poisson hôte / réchauffement climatique / modèles mixtes

\section{Introduction}

The cyclopoid family Lernaeidae includes freshwater species that are highly adapted to a parasitic way of life such as the anchor worm Lernaea cyprinacea L. (hereafter anchor worm), the only cosmopolitan species (Piasecki et al., 2004). Environmental factors, particularly water temperature and dissolved oxygen, and high fish densities have a key influence on the intensity of infestation of anchor worms (e.g. Perez-

\footnotetext{
* Corresponding author: javier.sanchez@usc.es
}

Bote, 2005; Plaul et al., 2010; Dalu et al., 2012). More specifically, water temperatures ranging from 25 to $28^{\circ} \mathrm{C}$ usually offer excellent conditions for parasite reproduction (Piasecki et al., 2004). The copepod anchor worm was introduced in the Iberian Peninsula from Asia, and first recorded in 1973 (Simon Vicente et al., 1973; Garcia-Berthou et al., 2007). The parasite causes Lerneosis (easily recognised due to the presence of skin lesions) to its host when attaching to the body, making the host to be more susceptible to secondary infections (Piasecki et al., 2004; Sánchez-Hernández, 2011). Additionally, the anchor worm has negative effects on the haematocrit values, body condition and growth of infected 
J. Sánchez-Hernández: Knowl. Manag. Aquat. Ecosyst. 2017, 418, 11

Table 1. Review of the available literature about the parasite infestation (Lernaea cyprinacea) on the Iberian ichthyofauna.

\begin{tabular}{|c|c|c|c|c|c|c|c|}
\hline Host species & $\begin{array}{l}\text { Species } \\
\text { type }\end{array}$ & Family & Locality & $\begin{array}{l}\text { Prevalence } \\
(\%)\end{array}$ & $\begin{array}{l}\text { Intensity } \\
\text { (mean) }\end{array}$ & $\begin{array}{l}\text { Abundance } \\
\text { (mean) }\end{array}$ & $\begin{array}{l}\text { Reference/map naming } \\
\text { convention }\end{array}$ \\
\hline Alosa alosa & Native & Clupeidae & Guadiana River & 4.3 & 1.0 & - & Perez-Bote (2005)/13 \\
\hline Barbus haasi & Endemic & Cyprinidae & Llobregat River & 31.5 & 2.6 & 0.8 & $\begin{array}{l}\text { Gutierrez-Galindo and } \\
\text { Lacasa-Millan (2005)/5 }\end{array}$ \\
\hline Carassius auratus & Alien & Cyprinidae & Esla River & - & - & - & $\begin{array}{l}\text { Simon Vicente et al. } \\
(1973) / 2\end{array}$ \\
\hline \multirow[t]{2}{*}{ Cyprinus carpio } & Alien & Cyprinidae & Llobregat River & 8.4 & 3.1 & 0.3 & $\begin{array}{l}\text { Gutierrez-Galindo and } \\
\text { Lacasa-Millan }(2005) / 5\end{array}$ \\
\hline & & & Retiro pond & 12.5 & - & - & Almeida et al. (2008)/10 \\
\hline Gobio lozanoi & Native & Cyprinidae & Duero River & 1.15 & - & - & Illán Aguirre (2012)/3 \\
\hline \multirow[t]{2}{*}{ Luciobarbus bocagei } & Endemic & Cyprinidae & Tormes River & - & - & - & $\begin{array}{l}\text { Simon Vicente } \text { et al. } \\
(1973) / 8\end{array}$ \\
\hline & & & Duero River & 12.0 & - & - & Illán Aguirre (2012)/7 \\
\hline Luciobarbus comizo & Endemic & Cyprinidae & Guadiana River & 55.7 & - & - & Perez-Bote (2010)/13 \\
\hline Luciobarbus graellsii & Endemic & Cyprinidae & Llobregat River & 39.2 & 4.6 & 1.8 & $\begin{array}{l}\text { Gutierrez-Galindo and } \\
\text { Lacasa-Millan (2005)/5 }\end{array}$ \\
\hline Luciobarbus sclateri & Endemic & Cyprinidae & Guadiana River & 57.4 & 1.8 & 1.0 & Perez-Bote $(2000) / 15$ \\
\hline $\begin{array}{l}\text { Parachondrostoma } \\
\text { miegii }\end{array}$ & Endemic & Cyprinidae & Ebro basin & - & - & - & Sterling et al. (1995)/4 \\
\hline $\begin{array}{l}\text { Pseudochondrostoma } \\
\text { duriense }\end{array}$ & Endemic & Cyprinidae & Duero River & 6.0 & - & - & Illán Aguirre (2012)/6 \\
\hline $\begin{array}{l}\text { Pseudochondrostoma } \\
\text { polylepis }\end{array}$ & Endemic & Cyprinidae & Arrocampo reservoir & - & - & - & Moreno et al. (1986)/12 \\
\hline $\begin{array}{l}\text { Pseudochondrostoma } \\
\text { willkommii }\end{array}$ & Endemic & Cyprinidae & Guadiana River & 89.1 & 3.7 & 3.3 & Perez-Bote (2000)/15 \\
\hline Salmo trutta & Native & Salmonidae & Tea River & 3.0 & - & - & Bao et al. (2016)/1 \\
\hline Squalius alburnoides & Endemic & Cyprinidae & Guadiana River & 30.2 & 1.4 & 0.4 & Perez-Bote (2000)/15 \\
\hline \multirow[t]{2}{*}{ Squalius cephalus } & Native & Cyprinidae & Frio River & 5.8 & - & - & $\begin{array}{l}\text { Saraiva and Valente } \\
(1988) / 14\end{array}$ \\
\hline & & & Llobregat River & 48.2 & 2.4 & 1.1 & $\begin{array}{l}\text { Gutierrez-Galindo and } \\
\text { Lacasa-Millan }(2005) / 5\end{array}$ \\
\hline
\end{tabular}

hosts, as well as inducing malformations (e.g. Kupferberg et al., 2009; Perez-Bote, 2010; Sánchez-Hernández, 2011). Thus, anchor worms can definitely compromise host performance.

Increasing temperatures are predicted to occur in the next few decades as a consequence of global change (e.g. Vautard et al., 2014). In fact, future high water temperatures are likely to affect parasite transmission, virulence and host-parasite interactions, with outbreaks being more frequent (Marcogliese, 2001). It is widely accepted that global warming might favour the anchor worms to invade new territories other than tropical countries, such as temperate or colder countries, because temperatures above $20^{\circ} \mathrm{C}$ promote its outbreak (Kupferberg et al., 2009). Although it is difficult to forecast host-parasite interactions under climate change scenarios, temperature increases could have adverse implications for fish populations because more generations annually and larger population sizes of parasites are expected to occur with global warming (Marcogliese, 2001).

The anchor worm has successfully established in some catchments of the Iberian Peninsula parasitising Cyprinidae, Salmonidae and Clupeidae species (see Tab. 1 for references). The aim of the present study was to review the existing body of knowledge on the anchor worm distribution and host species in the Iberian Peninsula. Additionally, this study aimed to assess the effects of climate on infestation levels of the species. Infestation levels of anchor worms are hypothesised to be positively correlated with higher water temperature (Marcogliese, 2001; Kupferberg et al., 2009). Thus, temperature was expected to shape infestation levels of the anchor worm. The connection between anchor worm infestation levels and temperature may allow for predicting how climate change is likely to affect the parasite, and consequently host-parasite interactions.

\section{Methods}

Two primary sources of data collection were used: (i) field fish surveys conducted in the headwater of the Tormes Basin (central Spain) during the summers of August 2010 and August 2016 and (ii) Web of Science and Dialnet were used to search for studies including records containing the key word 'Lernaea cyprinacea' in combination with either of the key words: 'prevalence', 'intensity', 'abundance', 'anchor worm', 'Spain' and 'Iberian Peninsula'. When geographical coordinates of the study area were not provided in the bibliographic source, the coordinates were derived from map coordinate conversion tools. 
J. Sánchez-Hernández: Knowl. Manag. Aquat. Ecosyst. 2017, 418, 11

Table 2. Prevalence, intensity and abundance of Lernaea cyprinacea on the fish species caught in the Tormes River during August 2010 and 2016. Number of fish examined $(n)$ and size (mean \pm SE).

\begin{tabular}{|c|c|c|c|c|c|c|c|}
\hline Host species & Species type & Family & $n$ & Size & Prevalence $(\%)$ & Intensity (mean) & Abundance (mean) \\
\hline Cobitis calderoni & Endemic & Cobitidae & 20 & $3.6 \mathrm{~cm} \pm 0.08$ & 10.0 & 1.0 & 0.1 \\
\hline Luciobarbus bocagei & Endemic & Cyprinidae & 9 & $6.6 \mathrm{~cm} \pm 1.97$ & $*$ & $*$ & $*$ \\
\hline Pseudochondrostoma duriense & Endemic & Cyprinidae & 47 & $9.1 \mathrm{~cm} \pm 0.41$ & $*$ & $*$ & $*$ \\
\hline Salmo trutta & Native & Salmonidae & 104 & $14 \mathrm{~cm} \pm 1.03$ & 19.3 & 2.1 & 0.4 \\
\hline Squalius carolitertii & Endemic & Cyprinidae & 57 & $6.5 \mathrm{~cm} \pm 0.28$ & 7.0 & 1.3 & 0.1 \\
\hline
\end{tabular}

* No parasitic anchor worm was found on the fish species.

The Tormes River is a typical oligotrophic system with conductivities generally below $45 \mu \mathrm{S} / \mathrm{cm}$ with a typical of snow-rainfall flow regime (Sánchez-Hernández and Nunn, 2016). The fish community in the headwater of the Tormes basin is mainly composed by native fish species: brown trout Salmo trutta Linnaeus, 1758, northern straight-mouth nase Pseudochondrostoma duriense (Coelho, 1985), northern Iberian chub Squalius carolitertii (Doadrio, 1988) and Iberian barbel Luciobarbus bocagei (Steindachner, 1864), although less frequently Northern Iberian spined-loach Cobitis calderoni Băcescu (1962) and Calandino Squalius alburnoides (Steindachner, 1866) are also present in the lower parts. Except for $S$. trutta, the Tormes ichthyofauna is composed of endemic species. $S$. trutta is the main top predator (Sánchez-Hernández, 2016).

The sampling during 2010 was conducted in a wadeable riffle section of the river (Ávila, $40^{\circ} 19^{\prime} \mathrm{N}, 5^{\circ} 29^{\prime} \mathrm{W}$ ), and the sampling site of 2016 was located in a pool (Ávila, $40^{\circ} 29^{\prime} \mathrm{N}$, $\left.5^{\circ} 31^{\prime} \mathrm{W}\right)$. Fishes were collected using pulsed direct-current backpack electrofisher equipment (Hans Grassl GmbH, ELT60II). In 2010, sampling was conducted to collect resident brown trout and potamodromous cyprinid species, whereas the survey of 2016 aimed to collect $C$. calderoni from the shore of the pool (non-wadeable). A total of 237 specimens was examined (Tab. 2). The external surface of each fish was examined. Prevalence (percentage of infested hosts in a sample), mean intensity (mean number of parasites per infested host) and mean abundance (mean number of parasites per host examined) were determined.

For the study on the relation between temperature and infestation, climate data based on eleven bioclimatic variables with a spatial resolution of about $1 \mathrm{~km}^{2}$ for the Iberian Peninsula were downloaded from Worldclim (http://www. worldclim.org/). More information about the methods used to generate climate data can be found in Hijmans et al. (2005). The temperature variables are given as supplementary material (Tab. S1). Although no water temperature was measured in this study, it should be noted that stream temperature and air temperature are highly correlated with each other (e.g. Morrill et al., 2005). HydroSHEDS database (http://hydrosheds.cr. usgs.gov) was used to define river networks and drainage basins. The distribution of the anchor worm was spatially matched with temperature data, river networks and drainage basins using the QGIS 2.16 (http://www.qgis.org/).

Prior to analyses, data normality was assessed using Shapiro-Wilk tests. Prevalence and abundance showed nonnormality $(W=0.877 ; P=0.005$ and $W=0.805 ; P=0.017$, respectively), whereas intensity showed normality ( $W=0.941$; $P=0.377)$. The relationship between infestation levels and temperature variables (Tab. S1) was tested using Pearson's rank correlation. Additionally, mixed modelling was used to identify the best predictor variables impacting on parasite infestation levels. As linear regression models require normality of the data (Zuur et al., 2009), generalised additive mixed models for nonnormal data (prevalence and abundance) and linear-mixed effects models for normal data (intensity) with river as a random factor in all cases were used. The random part contains components that allow for heterogeneity of variables among the studied rivers (Zuur et al., 2009). Model selection was done by model comparison using the 'MuMIn' library, comparing all possible combinations of fixed factors (here temperature variables) and ranked candidate models according to the Akaike information criterion (AIC, the best model being the one with the lowest AIC values). Residuals of the final selected model were visually inspected for deviations from normality and heteroscedasticity, without finding clear evidence for violation of model assumptions (see Appendix 1). Statistics and graphical outputs were performed using R 3.2.2 (R Core Team, 2015). A significance level of $P=0.05$ was used in all analyses.

\section{Results}

Sixteen freshwater fish species distributed in nine genera and three families (Cyprinidae, Clupeidae and Salmonidae) are hosts with prevalence values between $3 \%$ and $89.1 \%$ (Tab. 1). Two of these species were introduced and 14 are native, of which 12 are endemic species (Tab. 1). In the Tormes River, the anchor worm was observed on $S$. carolitertii, $C$. calderoni and $S$. trutta with low prevalence values (below 20\%, Tab. 2). Most records are from south-western and central watersheds (Fig. 1).

Mixed modelling indicated a strong positive effect of mean temperature of warmest quarter (a quarter is a period of three months) on prevalence values of the anchor worm, whereas mean temperature of wettest quarter and annual mean temperature seem to impact on intensity and abundance levels, respectively (Tab. 3). Additionally, prevalence increases with annual mean temperature and max temperature of warmest month $(r=0.514 ; P=0.029$ and $r=0.534 ; P=0.022$, respectively). No significant correlations between the remaining temperature variables and infestation levels of anchor worm were found. 


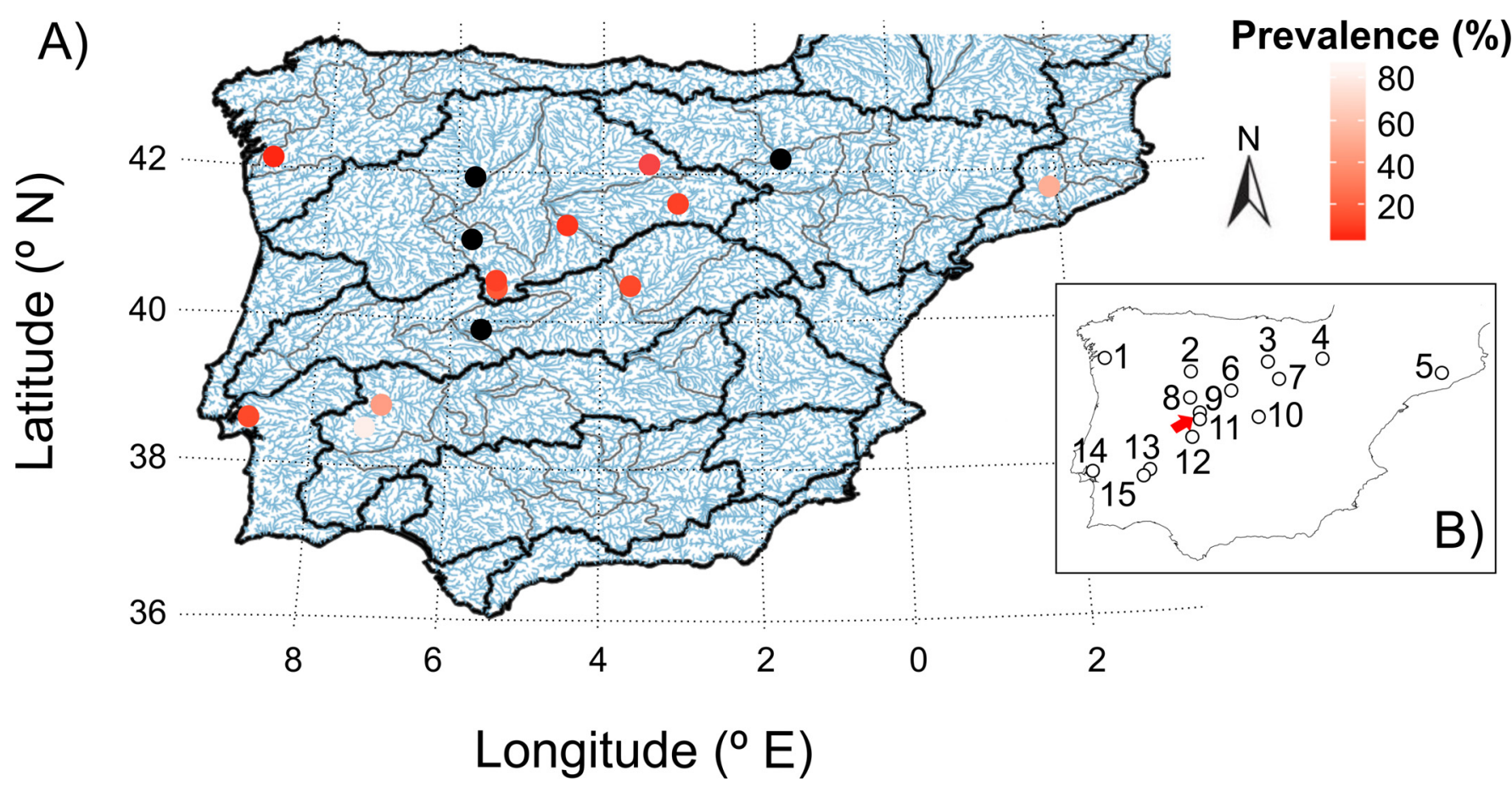

Fig. 1. Map of the Iberian Peninsula with the distribution of the non-native parasitic anchor worm (Lernaea cyprinacea). (A) The Iberian Peninsula showing the river networks (blue lines), river basins (grey lines), drainage basins (black lines) and prevalence values (red dots). Black dots show localities without prevalence values. (B) Bibliographic source (refer to Tab. 1 for bibliographic naming conventions). The localities of the field study are marked with a red arrow (numbers: 9 and 11).

Table 3. Summary table of the best model simulation for prevalence, intensity and abundance according to AIC values. $t$ - and $P$-values for parameter estimates are shown in parentheses. Annual mean temperature (BIO1), mean temperature of wettest quarter (BIO8) and mean temperature of warmest quarter (BIO10).

\begin{tabular}{lllll}
\hline Variable & Intercept & \multicolumn{2}{c}{ Predictor variables } \\
\cline { 3 - 5 } & & $\begin{array}{l}\text { Annual mean } \\
\text { temperature (BIO1) }\end{array}$ & $\begin{array}{l}\text { Wettest quarter } \\
\text { temperature (BIO8) }\end{array}$ & $\begin{array}{l}\text { Warmest quarter } \\
\text { temperature }(\mathrm{BIO} 10)\end{array}$ \\
\hline Prevalence & $-103.38(t=-2.40 ; P=0.028)$ & - & - & $0.60(t=2.99 ; P=0.009)$ \\
Intensity & $1.04(t=1.72 ; P=0.128)$ & - & $0.01(t=2.35 ; P=0.051)$ & - \\
Abundance & $-1.64(t=-1.18 ; P=0.271)$ & $0.02(t=1.89 ; P=0.096)$ & - & - \\
\hline
\end{tabular}

\section{Discussion}

This study updates the list of the host species for the anchor worm in the Iberian Peninsula up to 18 as a novel observation of the anchor worm on $C$. calderoni (family Cobitidae) and $S$. carolitertii (family Cyprinidae) is described from the Tormes River. Overall, most records are from south-western and central watersheds, with little or no information from other watersheds of the Iberian Peninsula (Fig. 1). Cyprinids emerged as the main host in the Iberian Peninsula (15 out of 18). Although all fish species may be not equally suited as hosts, the number of hosts species could be potentially higher because the Iberian ichthyofauna includes 35 cyprinid species (31 native and 4 introduced species) and a total of 89 species (Doadrio et al., 2011).

The highest parasite prevalence was found in Pseudochondrostoma willkommii, Luciobarbus sclateri and Luciobarbus comizo, with $>50 \%$ prevalence from the Guadiana River
(Perez-Bote, 2000) in comparison with non-cyprinid species such as S. trutta and Alosa alosa (Perez-Bote, 2005; SánchezHernández, 2011; Bao et al., 2016). Prevalence values were also low for the species inhabiting the Tormes River. Noteworthy, prevalence varied considerably among watersheds, and also between studies of the same species. This high variation might be related to site-specific environmental conditions such as temperature.

In fact, previous studies have found that rising temperatures are likely to lead to increased parasite infestation levels (e.g. Kupferberg et al., 2009; Zamora-Vilchis et al., 2012). Increases in summer water temperatures (i.e. above $20^{\circ} \mathrm{C}$ ) promote outbreaks of anchor worm (Kupferberg et al., 2009). Likewise, Plaul et al. (2010) noted that prevalence and intensity of infection reduce with decreases in water temperature. However, Dalu et al. (2012) observed that parasite intensity can be negatively correlated with water temperature in tropical areas. Because the optimum temperature for the anchor worm is between $23^{\circ} \mathrm{C}$ 
and $30^{\circ} \mathrm{C}$ (Plaul et al., 2010), the negative relationship observed by Dalu et al. (2012) may be related to parasite thermal tolerances, as water temperature exceeded the tolerance thresholds (mean values from $19.3{ }^{\circ} \mathrm{C}$ to $30.1^{\circ} \mathrm{C}$ in July and March, respectively). This study is in agreement with the abovementioned studies supporting the hypothesis that high water temperatures within parasite thermal tolerances can increase infestation levels and consecutively promote host-parasite interaction. Broadly, this study suggests that host-parasite interactions in riverine systems might be exacerbated by the direct effects of global warming. In this sense, it is widely accepted that global warming should favour cyprinid species over other fish species such as salmonids (Sánchez-Hernández and Nunn, 2016 and references therein). Thus, it seems reasonable to posit that anchor worm will be positively affected by direct and indirect effects (temperature and distribution/ abundance of cyprinid species, respectively) under the ongoing climate change in temperate and colder regions. This hypothetical beneficial scenario for the anchor worm could lead to detrimental impacts on host fish species via increases in infestation levels. However, this conclusion should be taken with some caution because how anchor worm will respond to new environmental conditions with the ongoing global warming is entirely unknown.

From fishery management and conservation perspectives, managers often emphasise the beneficial effects of the stocking programmes for the conservation of native fish stocks (e.g. Marco-Rius et al., 2013). These programmes consist in capture wild individuals, spawn them in fish farms and then realise fertilised eggs and/or juveniles in aquatic systems. For example, wild $S$. trutta of the headwater of the Tormes basin is currently used for stocking programmes, and the risk of using infested fish may exist. In this respect, management actions should therefore protect free-parasite watersheds avoiding disease transmission through translocations of infected fish. This can be accomplished with this study, because it is the first attempt to map the distribution of anchor worm (L. cyprinacea) in the Iberian Peninsula. This specific example focused on the anchor worm should be contextualised in a wider context, ideally taking into account its whole distribution as well as other non-native parasitofauna of freshwater fish species. It should be kept in mind that parasites of freshwater fishes are often poorly studied, and additional work is needed to identify parasites distribution and host specificity (e.g. Quiroz-Martínez and Salgado-Maldonado, 2013; Scholz and Choudhury, 2014). That said, future monitoring programmes still need to take into account parasite protocols in order to improve the knowledge about distribution, disease threats, epidemiology and spatiotemporal variation of non-native parasites in nature (Williams et al., 2013). Additionally, other management actions can be pursued to diminish the effects of non-native parasites such as eradication and control programmes of either hosts or pathogens (e.g. Johnsen et al., 1989; Lymbery et al., 2014).

\section{Supplementary Material}

Table S1 Temperature variables as on the Bioclim website (http://www.worldclim.org/bioclim).

The Supplementary Material is available at http://www. kmae-journal.org/10.1051/kmae/2017002/olm.
Acknowledgements. I appreciate constructive comments from Daniel Gerdeaux and two anonymous referees, which considerably improved the quality of the manuscript. J. Sánchez-Hernández was supported by a postdoctoral grant from the Galician Plan for Research, Innovation, and Growth 2011-2015 (Plan I2C, Xunta de Galicia).

\section{References}

Almeida D, Almodovar A, Nicola GG, Elvira B. 2008. Fluctuating asymmetry, abnormalities and parasitism as indicators of environmental stress in cultured stocks of goldfish and carp. Aquaculture 279: 120-125.

Bao M, Costal D, Garci ME, Pascual S, Hastie LC. 2016. Sea lice (Lepeophtheirus salmonis) and anchor worms (Lernaea cyprinacea) found on sea trout (Salmo trutta) in the River Minho catchment, an important area for conservation in NW Spain. Aquat Conserv: Mar Freshwater Ecosyst 26: 386-391.

Dalu T, Nhiwatiwa T, Clegg B, Barson M. 2012. Impact of Lernaea cyprinacea Linnaeus 1758 (Crustacea: Copepoda) almost a decade after an initial parasitic outbreak in fishes of Malilangwe Reservoir, Zimbabwe. Knowl Manag Aquat Ecosyst 406: 1-9.

Doadrio I, Perea S, Garzón-Heydt P, González JL. 2011. Ictiofauna Continental Española. Bases para su Seguimiento. Dirección General Medio Natural y Política Forestal. Ministerio de Medio Ambiente y Medio Rural y Marino, Madrid, 610 p. (in Spanish).

Garcia-Berthou E, Boix D, Clavero M. 2007. Non-indigenous animal species naturalized in Iberian inland waters. In: Gherardi F, ed. Biological invaders in inland waters: profiles, distribution and threats. Netherlands: Springer, pp. 123-138.

Gutierrez-Galindo JF, Lacasa-Millan MI. 2005. Population dynamics of Lernaea cyprinacea (Crustacea: Copepoda) on four cyprinid species. Dis Aquat Organ 67: 111-114.

Hijmans RJ, Cameron SE, Parra JL, Jones PG, Jarvis A. 2005. Very high resolution interpolated climate surfaces for global land areas. Int J Climatol 25: 1965-1978.

Illán Aguirre G. 2012. Descripción y caracterización epidemiológica de la parasitofauna de peces ciprínidos de la cuenca alta y media del río Duero. PhD Thesis, University of Zaragoza, 409 p. (in Spanish).

Johnsen BO, Jensen AJ, Sivertsen B. 1989. Extermination of Gyrodactylus salaris - infected Atlantic salmon Salmo salar by rotenone treatment in the river Vikja, Western Norway. Fauna Nor $\operatorname{Ser} A$ 10: 39-43.

Kupferberg SJ, Catenazzi A, Lunde K, Lind AJ, Palen WJ. 2009. Parasitic copepod (Lernaea cyprinacea) outbreaks in foothill yellow-legged frogs (Rana boylii) linked to unusually warm summers and amphibian malformations in Northern California. Copeia 2009: 529-537.

Lymbery AJ, Morine M, Kanani HG, Beatty SJ, Morgan DL. 2014. Co-invaders: the effects of alien parasites on native hosts. Int $J$ Parasitol Parasites Wildl 3: 171-177.

Marcogliese DJ. 2001. Implications of climate change for parasitism of animals in the aquatic environment. Can J Zool 79: 1331-1352.

Marco-Rius F, Sotelo G, Caballero P, Morán P. 2013. Insights for planning an effective stocking program in anadromous brown trout (Salmo trutta). Can J Fish Aquat Sci 70: 1092-1100.

Moreno O, Granado-Lorencio C, Garcia-Novo F. 1986. Variabilidad morfológica de Lernaea cyprinacea (Crustacea: Copepoda) en el embalse de Arrocampo (Cuenca de Tajo: Caceres). Limnetica 2: 265-270 (in Spanish).

Morrill JC, Bales RC, Conklin MH. 2005. Estimating stream temperature from air temperature: implications for future water quality. $J$ Environ Eng 131: 139-146. 
Perez-Bote JL. 2000. Occurrence of Lernaea cyprinacea (Copepoda) on three native cyprinids in the Guadiana River (SW Iberian Peninsula). Res Rev Parasitol 60: 135-136.

Perez-Bote JL. 2005. First Record of Lernaea cyprinacea (Copepoda: Cyclopoida) on the Allis Shad. Folia Biol 53: 197-198.

Perez-Bote JL. 2010. Barbus comizo infestation by Lernaea cyprinacea (Crustacea: Copepoda) in the Guadiana River, southwestern Spain. J Appl Ichthyol 26: 592-595.

Piasecki W, Goodwin AE, Eiras JC, Nowak BF. 2004. Importance of copepoda in freshwater aquaculture. Zool Stud 43: 193-205.

Plaul SE, Garcia Romero N, Barbeito CG. 2010. Distribution of the exotic parasite, Lernaea cyprinacea (Copepoda, Lernaeidae) in Argentina. Bull Eur Ass Fish Pathol 30: 65-73.

Quiroz-Martínez B, Salgado-Maldonado G. 2013. Patterns of distribution of the helminth parasites of freshwater fishes of Mexico. PLoS One 8: e54787.

R Core Team. 2015. R: a language and environment for statistical computing. Vienna: R Foundation for Statistical Computing.

Sánchez-Hernández J. 2011. Infestation of Lernaea cyprinacea (Crustacea, Copepoda) on wild brown trout in Spain. Bull Eur Ass Fish Pathol 31: 119-123.

Sánchez-Hernández J. 2016. Do age-related changes in feeding habits of brown trout alter structural properties of food webs? Aquat Ecol 50: 685-695.

Sánchez-Hernández J, Nunn AD. 2016. Environmental changes in a Mediterranean river: implications for the fish assemblage. Ecohydrology 9: 1439-1451.
Saraiva A, Valente ACN. 1988. Black spot disease and Lernaea sp. infestation on Leuciscus cephalus L. (Pisces: Cyprinidae) in Portugal. Bull Eur Ass Fish Pathol 8: 7-8.

Scholz T, Choudhury A. 2014. Parasites of freshwater fishes in North America: why so neglected? J Parasitol 100: 26-45.

Simon Vicente F, Ramajo V, Encinas A. 1973. Fauna parasitaria de peces españoles de agua dulce: Allocreadium isoporum (Trematoda: Allocreadidae); Lernaea esocina; L. cyprinacea y Ergasilus sp. (Crustacea: Copepoda). Rev Ibérica Parasitol 33: 633-647 (in Spanish).

Sterling JE, Carbonell E, Estellés-Zanón EJ, Chirivella J. 1995. Estudio estacional del parasitismo por Lernaea cyprinacea en la madrilla Chondrostoma toxostoma miegii (Pisces: Cyprinidae) en un afluente del río Ebro. Proc. 4th Iber. Cong. Parasitol., Santiago de Compostela, Spain, 90-91 (in Spanish).

Vautard R, Gobiet A, Sobolowski S, et al. 2014. The European climate under a $2^{\circ} \mathrm{C}$ global warming. Environ Res Lett 9: 034006.

Williams CF, Britton JR, Turnbull JF. 2013. A risk assessment for managing non-native parasites. Biol Invasions 15: 12731286.

Zamora-Vilchis I, Williams SE, Johnson CN. 2012. Environmental temperature affects prevalence of blood parasites of birds on an elevation gradient: implications for disease in a warming climate. PLoS One 7: e39208

Zuur AF, Ieno EN, Walker NJ, Saveliev AA, Smith GM. 2009. Mixed effects models and extensions in ecology with R. New York, NY, USA: Springer Science \& Business Media, 574 p.

\section{Appendix 1 Residual plots for the mixed effect modelling}

\section{$\underline{\text { Prevalence }}$}

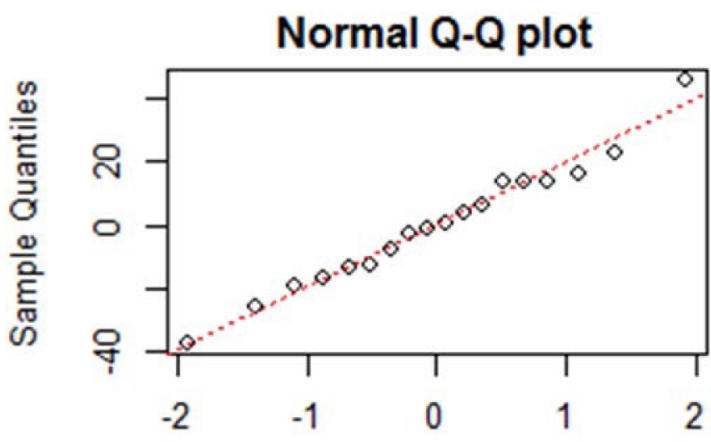

Theoretical Quantiles

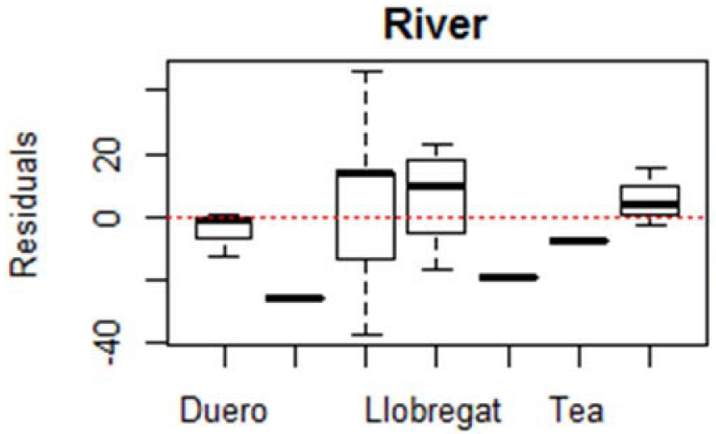

Histogram of residuals

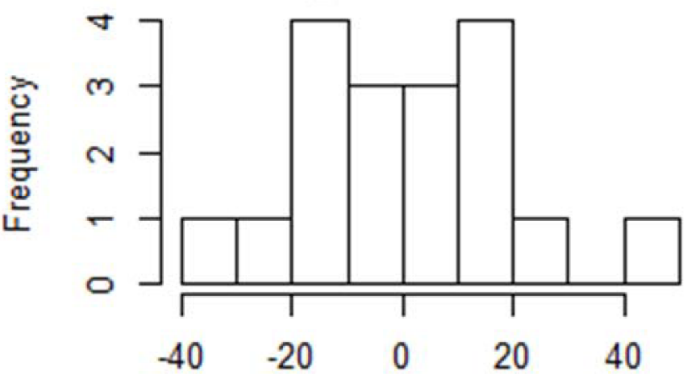

Residuals

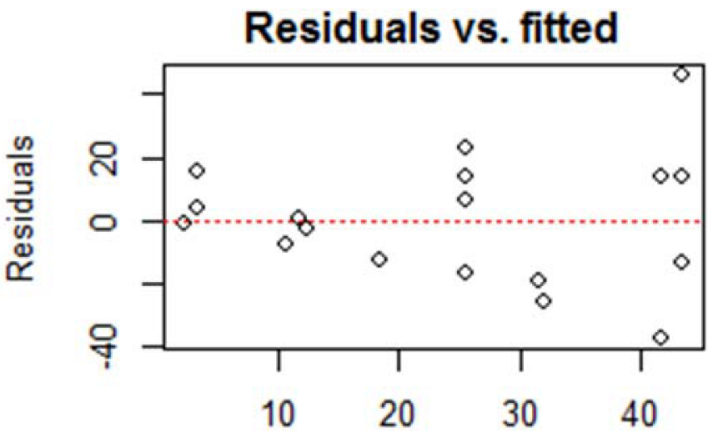

Fitted values 
J. Sánchez-Hernández: Knowl. Manag. Aquat. Ecosyst. 2017, 418, 11

Intensity
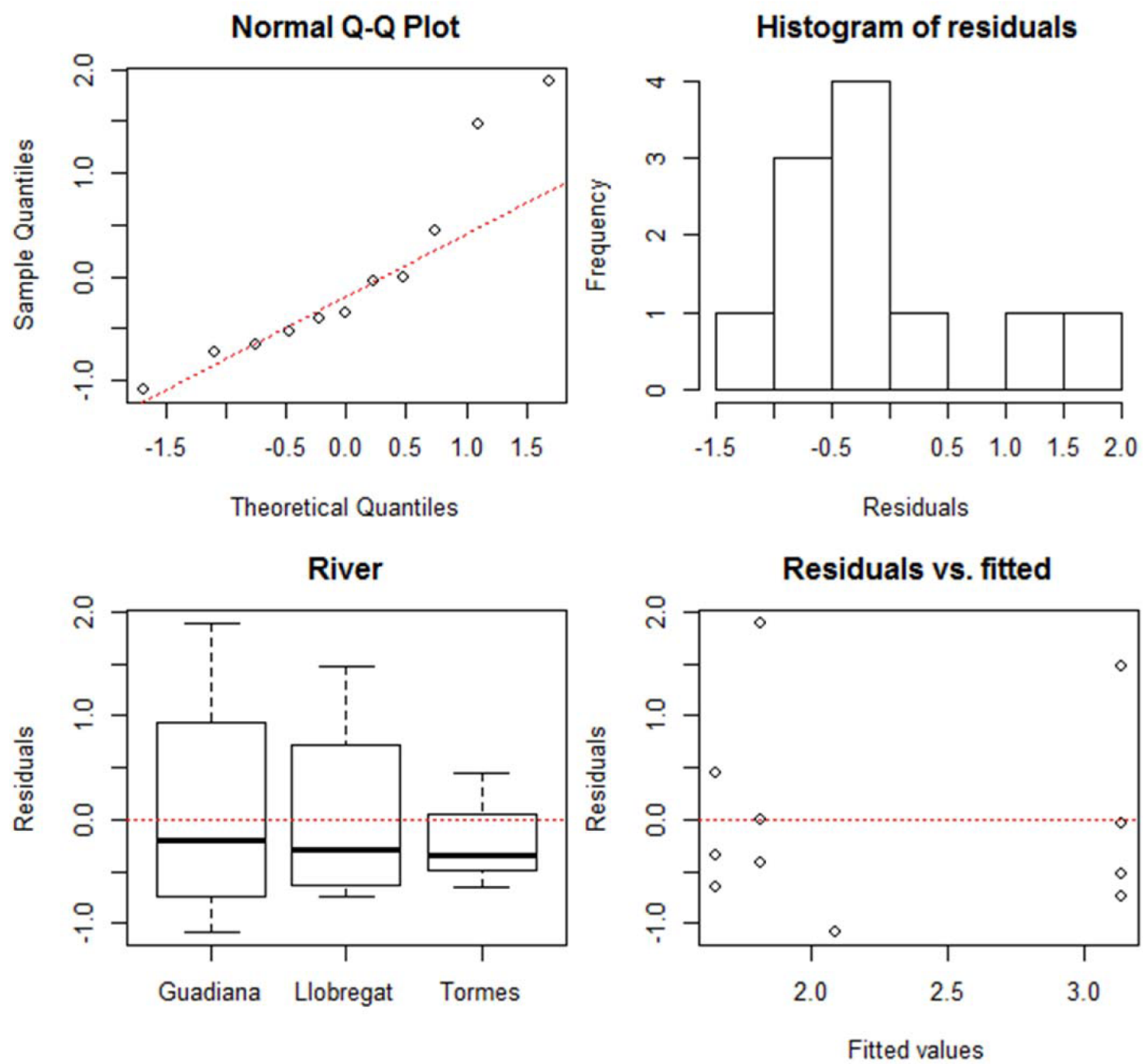


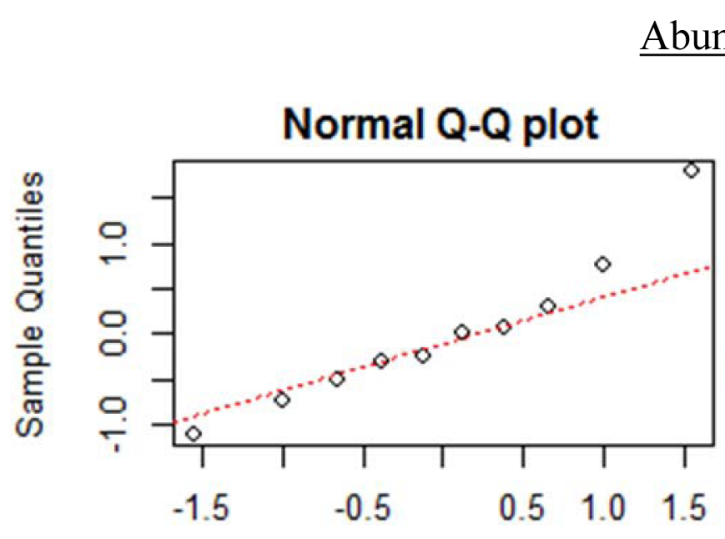

Theoretical Quantiles

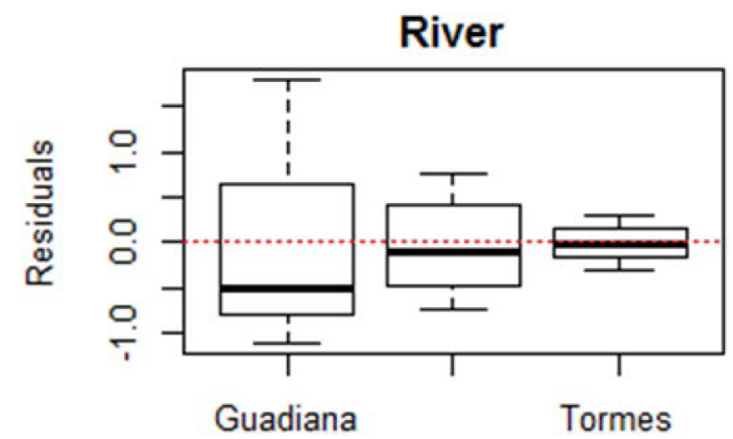

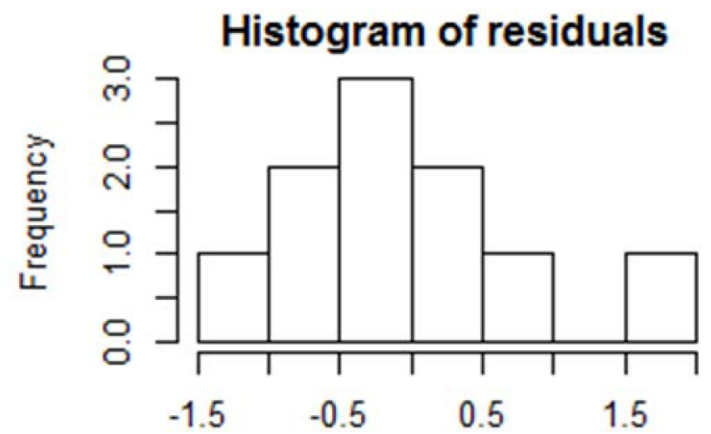

Residuals

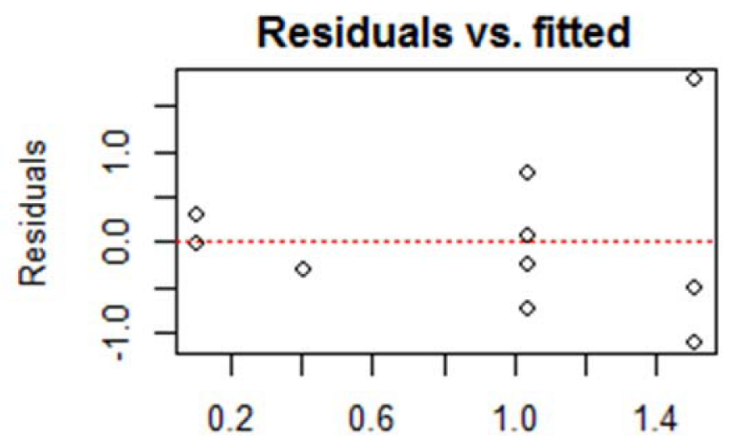

Fitted values

Cite this article as: Sánchez-Hernández J. 2017. Lernaea cyprinacea (Crustacea: Copepoda) in the Iberian Peninsula: climate implications on host-parasite interactions. Knowl. Manag. Aquat. Ecosyst., 418, 11. 